\title{
ArcheoSciences
}

Revue d'archéométrie

43-2 | 2019

Varia

\section{Les céramiques anciennes sous le regard des archéosciences}

Ancient Ceramics in the Scope of Archaeosciences

Nadia Cantina, Ayed Ben Amara et Rémy Chapoulie

\section{(2) OpenEdition}

1 Journals

Édition électronique

URL : https://journals.openedition.org/archeosciences/6501

DOI : 10.4000/archeosciences. 6501

ISSN : 2104-3728

Éditeur

Presses universitaires de Rennes

Édition imprimée

Date de publication : 31 décembre 2019

Pagination : 145-148

ISBN : 978-2-7535-8194-4

ISSN : 1960-1360

\section{Référence électronique}

Nadia Cantina, Ayed Ben Amara et Rémy Chapoulie, «Les céramiques anciennes sous le regard des archéosciences », ArcheoSciences [En ligne], 43-2 | 2019, mis en ligne le 26 novembre 2020, consulté le 02 janvier 2023. URL : http://journals.openedition.org/archeosciences/6501 ; DOI : https://doi.org/ 10.4000/archeosciences.6501 


\title{
Les céramiques anciennes
}

\section{sous le regard des archéosciences}

\author{
Ancient Ceramics in the Scope of Archaeosciences
}

\author{
Nadia Cantin ${ }^{a}$, Ayed Ben Amara ${ }^{a}$ et Rémy Chapoulie ${ }^{a}$
}

\begin{abstract}
Résumé : Le colloque EMAC (European Meeting on Ancient Ceramic) organisé en 2017 à Bordeaux a rassemblé des chercheurs des sciences des matériaux et des sciences humaines. Cette quatorzième édition a donné lieu à la publication de 14 articles autour des thèmes principalement explorés ces dernières années en Europe. Des questions de provenance à la mise en évidence de technologies de fabrication, le matériau céramique apparaît plus que jamais comme un vecteur d'informations dans une vision intégrée de la recherche archéologique.
\end{abstract}

\begin{abstract}
The EMAC (European Meeting on Ancient Ceramic) symposium in 2017 in Bordeaux brought together researchers from the material sciences and humanities. This fourteenth edition gave rise to the publication of 14 articles on themes mainly explored in recent years in Europe. From questions of provenance to the highlighting of manufacturing technologies, the ceramic material appears more than ever as a vector of information in an integrated vision of archaeological research.
\end{abstract}

Mots clés : Céramique, archéologie, provenance, matières premières.

Keywords: Ceramic, archaeology, provenance, raw materials.

Le colloque EMAC (European Meeting on Ancient Ceramic) réunit tous les deux ans depuis 1991 des chercheurs principalement européens des sciences des matériaux et des sciences humaines. L'édition 2017 a été organisée à Bordeaux par le laboratoire IRAMAT-CRP2A (UMR 5060) de l'université Bordeaux Montaigne et le CNRS pendant 4 jours (du 6 au 9 septembre). Cette $14^{\mathrm{e}}$ rencontre a accueilli 150 participants de 20 nationalités et a illustré une fois de plus le dynamisme de la recherche autour de l'étude des céramiques anciennes.

Conformément aux éditions précédentes, cette $14^{\mathrm{e}}$ rencontre a favorisé les études interdisciplinaires et intégrées afin de questionner les sociétés anciennes. Le matériau céramique apparaît plus que jamais comme un vecteur d'information de nos sociétés du passé et un formidable lien avec celle(s) d'aujourd'hui. Plusieurs aspects ont été abordés au cours de ce temps scientifique découpé en huit sessions correspondant aux thèmes développés dans la plupart des laboratoires en Europe et plus largement dans le monde : études des matières premières et de leur disponibilité dans l'environnement, les gestes et les techniques, la fonction et l'utilisation de la céramique, la provenance et les réseaux de diffusion et d'échanges, les engobes et émaux, les nouvelles méthodes et méthodologies et l'analyse des données, enfin la chronologie et les céramiques techniques. Au final, 57 communications orales et 117 présentations de posters ont illustré ces différents thèmes de manière diachronique.

Quatorze articles ont été sélectionnés pour publication et ils se répartissent dans trois numéros de la revue ArcheoSciences-Revue d'Archéométrie (numéros 43(1), 43(2) publiés en 2019 et 44(1) publié en 2020). La plupart s'intéresse de manière diachronique à la problématique de la provenance avec pour finalité la recherche d'origine

a. IRAMAT CRP2A, UMR 5060, CNRS, Université Bordeaux Montaigne, Maison de l'Archéologie, Esplanade des Antilles 33607 Pessac, France. 
des objets qui vise à mieux comprendre leur circulation et leurs réseaux de diffusion (Maritan et al., 2019; Nagy et al., 2019; Fantuzzi et al., 2019) mais aussi des déplacements de population. Ainsi les travaux d'Inacio et al. (2019) mettent en lumière les relations entre stratégies d'approvisionnement et les modes de peuplement. D'autre part, l'analyse du matériau céramique permet de rechercher la provenance des matières premières qui vise, elle, à mieux comprendre les processus d'approvisionnement et de fabrication (Bugoï et al., 2019; Fusaro et al., 2019; Cau Ontiveros et al., 2020). D'autres travaux sont eux focalisés sur des périodes charnières marquées par des transitions technologiques comme celle de la romanisation et sur l'utilisation dans l'architecture des matériaux céramiques (Raneri et al., 2019). Deux autres articles s'intéressent à l'origine des carreaux émaillés de poêles dans l'est de la France (Bauer et al., 2019) et en Hongrie et Slovaquie (Gyorkos et al., 2019). Même si beaucoup de recherches s'intéressent à l'étude de la pâte, certaines portent une attention particulière aux décors et couleurs comme vecteur d'informations technologiques d'importance (Charpentier et al., 2019). Par ailleurs l'approche méthodologique centrée autour de la dilatométrie,

The European Meeting on Ancient Ceramics (EMAC) is a biennial conference convening researchers from humanities and sciences. The 2017 edition was organized by the IRAMAT-CRP2A (UMR5060) laboratory from Bordeaux Montaigne University and the CNRS for 4 days ( $\sigma^{\text {th }}$ to $9^{\text {th }}$ of September). This scientific congress organized in the metropolis of Bordeaux, followed a series of 13 EMAC congresses. This $14^{\text {th }}$ EMAC hosted 150 participants from twenty different nationalities and illustrated once again the dynamism of research around the study of ancient ceramics.

Just as was the case in former editions, this $14^{\text {th }}$ meeting promoted interdisciplinary and integrated studies of ancient ceramics in order to question ancient societies. The ceramic material appears more than ever as a vector of information for ancient societies and a formidable link with today's society. Several aspects were dealt with during this scientific event with eight sessions corresponding to the themes developed in most laboratories in Europe and more widely in the world: environmental and raw material studies, gestures and techniques, ceramic function and use, provenance and networks, slips and glazes, new methods and methodologies and data analyses, chronology and technical ceramics. In the end, 57 oral communications conduite par Thirion-Merle et al. (2019), permet de mieux comprendre les pratiques autour de la sélection de vases à des fins funéraires. L'utilisation des statistiques pour l'analyse de corpus d'ateliers s'avèrent de précieux outils pour explorer les processus de fabrication et la compréhension de leur variabilité au cours du temps (Emami et al., 2020). Enfin, un article traite de la spécificité des matériaux pour un usage technique. C'est le cas avec les céramiques employées pour la métallurgie du cuivre (Géraud et al., 2019).

Les organisateurs tiennent à remercier les membres du Comité Scientifique de l'EMAC et tous les chercheurs sollicités pour évaluer les résumés et réviser les articles, ainsi que la revue ArcheoSciences-Revue d'Archéométrie et son équipe éditoriale. Enfin nos remerciements s'adressent aux institutions qui, par leur soutien financier, ont largement contribué à la réalisation de ce congrès international et à sa publication : université Bordeaux Montaigne, Centre National de la Recherche Scientifique (CNRS), Laboratoire d'Excellence des Sciences Archéologiques de Bordeaux (LabEx LaScArBx; ANR-10-LABX-52), Fédération des Sciences Archéologiques de Bordeaux, Université de Bordeaux et Région Nouvelle-Aquitaine.

and 117 poster presentations illustrated these different themes in a diachronic way.

Fourteen articles have been selected for publication and they are distributed in three issues of the journal ArcheoSciencesRevue d'Archéométrie (issues 43-1, 43-2 published in 2019 and 44-1 published in 2020). Most of them deal diachronically with the problem of provenance with the aim of researching the origin of objects in order to better understand their circulation and distribution networks (Maritan et al., 2019; Nagy et al., 2019; Fantuzzi et al., 2019) but also population movements. Thus the work of Inacio et al. (2019) highlights the relations between supply strategies and settlement patterns. On the other hand, the analysis of the ceramic material allows to search for the origin of the raw materials which aims at better understanding the processes of supply and manufacturing (Bugoï et al., 2019; Fusaro et al., 2019; Cau Ontiveros et al., 2020). Other works focus on pivotal periods marked by technological transitions such as Romanization and the use of ceramic materials in architecture (Raneri et al., 2019). Two other papers focus on the origin of glazed stove tiles in eastern France (Bauer et al., 2019) and in Hungary and Slovakia (Gyorkos et al., 2019). Although many studies focus on the study of the paste, 
some pay particular attention to decorations and colours as a vector of important technological information (Charpentier et al., 2019). In addition, the methodological approach centered around dilatometry, conducted by Thirion-Merle et al. (2019), provides a better understanding of the practices surrounding the selection of vases for funerary purposes. The use of statistics for the analysis of workshop corpuses is proving to be a valuable tool for exploring manufacturing processes and understanding their variability over time (Emami et al., 2020). Finally, an article deals with the specificity of materials for technical use. This is the case with ceramics used for copper metallurgy (Géraud et al., 2019).
The organizers wish to thank the members of the Scientific Committee and all researchers who evaluated the abstracts and reviewed the submitted articles, and the ArcheoSciences-Revue d'Archéométrie journal and its editorial team. The following institutions contributed greatly to help achieve this international congress and its publication: the University Bordeaux Montaigne, the French National Center for Scientific Research (CNRS), the Bordeaux Archaeological Sciences Cluster of Excellence (ANR-10-LABX-52), the Bordeaux Archaeological Sciences Federation, the University of Bordeaux and the Nouvelle-Aquitaine Region.

\section{Références}

Bauer D., Ben Amara A., Cantin N., 2019. La céramique de poêle du site Berg Armo (XVI s., Sainte-Marie-aux-Mines, France) : matériaux et techniques de fabrication, ArcheoSciences-Revue d'Archéométrie, 43(2): 275-286.

Cau Ontiveros M. A., Fantuzzi L., Tsantini E., Mas Florit C., Chávez-Álvarez E., 2020. Archaeometric characterization of water jars from the Muslim period at the city of Pollentia (Mallorca, Balearic Islands), ArcheoSciences-Revue d'Archéométrie, 44(1): in press.

Charpentier A., Terrasse M., Bachir R., Ben Amara A., 2019. Palais du Meshouar (Tlemcen, Algérie) : couleurs des zellijs et tracés de décors du XIv siècle, ArcheoSciences-Revue d'Archéométrie, 43(2): 265-274.

Emami M., Emami S. N. (2020). A time-dependent statistical evaluation of the ceramic manufacturing process based on the mineralogical chemical analysis, ArcheoSciences-Revue d'Archéométrie, 44(1): in press.

Fantuzzi L., Cau Ontiveros M. A., Macias Solé J. M., Rodríguez Martorell F., 2019. Eastern Mediterranean amphorae from Late Antique urban centers of the northeastern Iberian Peninsula: archaeometric characterization, ArcheoSciences-Revue d'Archéométrie, 43(2): $229-247$.

Fusaro A., Martínez Ferrera S V., Gurt Esparraguera J. M., Angourakis A., Pidaev S. R., Baratova L., 2019. Islamic pottery from ancient Termez (Uzbekistan): new archaeological and archaeometric data, ArcheoSciences-Revue d'Archéométrie, 43(2): $249-264$.

Géraud M., Flament J., Hunt A., Sarah G., Foy E., Téreygeol F., 2019. Les céramiques métallurgiques de Castel-Minier (Ariège, France) $\mathrm{XIII}^{\mathrm{e}}$-Xv ${ }^{\mathrm{e}}$ siècle, ArcheoSciences-Revue d'Archéométrie, 43(1), 83-95.

Györkös D., Bajnóczi B., Szakmány G., Szabó M., Tóth M., 2019. Petrographic and XRD analysis of the ceramic body of late medieval Besztercebánya/Banská Bystrica-type stove tiles, ArcheoSciences-Revue d'Archéométrie, 43(2): 287-294.

Ignat T., Luca A., Dimofte D., Lazăr C., Constantin F., Bugoi R., 2019. Multidisciplinary study on prehistoric pottery from South Eastern Romania, ArcheoSciences-Revue d'Archéométrie, 43(2): 165-185.

Inácio N., Gonçalves V. S., Sousa A. C., 2019. Technology and mobility: First pottery productions in western Iberian Peninsula (Tagus estuary, Portugal), ArcheoSciences-Revue d'Archéométrie, 43(2): 149-164.

Maritan L., Mazzoli C., Mazzocchin S., Cipriano S., 2019. Wine and oil amphorae in Northern Adriatic Italy, ArcheoSciences-Revue d'Archéométrie, 43(2): 203-210.

Nagy A. A., Szakmány G., 2019. Amphorae as indicators of trade and diet in cibalae (Pannonia), ArcheoSciences-Revue d'Archéométrie, 43(2): 211-227.

Raneri S., Torre R., Mazzoleni P., Portale C., Barone G., 2019. From $\beta \alpha \lambda \alpha v \varepsilon i \alpha$ to thermae: unveiling the transition from Greek to Roman architectural models of baths by technological and provenance archaeometric studies on bricks and tiles, ArcheoSciences-Revue d'Archéométrie, 43(2): 187-202.

Thirion-Merle V., Batigne Vallet C., Bonnet C., Vernet A., 2019. The use of dilatometry in determining the manner of selecting ossuary vases: the case of Lugdunum during the Early Roman Empire, ArcheoSciences-Revue d'Archéométrie, 43(1): 97-106. 